\title{
First Human Trial of Synthetic Birth-control Vaccine Begun in Australia*
}

Thirty women volunteered for the world's first human trial of a synthetic birth-control vaccine, which began in February 1986 in Adelaide, Australia - at Flinders Medical Centre, a collaborating centre of the World Health Organization (WHO). The trial, which is part of WHO's Special Programme of Research, Development, and Research Training, in Human Reproduction, is scheduled to last for nine months, and aims to determine the safety and sideeffects of the vaccine in already-sterilized women.

If this trial is successful, the vaccine will be tested on fertile women to determine its efficacy as a birth-control method. Also to be determined is the duration of the vaccine's effect, which is foreseen as likely to be between one and two years. WHO estimates that, if all the trials proceed satisfactorily, the vaccine could be available by the mid1990s.

The vaccine was developed by Ohio State University (USA), in collaboration with other academic institutions, the pharmaceutical industry, and WHO, over the past

\footnotetext{
* On learning of this event we asked the President of Negative Population Growth, Inc., Donald Mann, for a comment and he replied (in litt. 24 March 1986) that he did not feel qualified to give an opinion on what he referred to as 'a most interesting and promising development, indeed', but added: 'Our viewpoint is that while improved contraceptives are essential, the heart of the matter [lies in] motivating couples to have not more than one child or two children at the most'-see also the Guest Comment by Professor Gordon L. Ada on page 100 of this issue.-Ed.
}

decade. It has already been shown to be safe in several animal species, and to prevent pregnancy in baboons.

'The vaccine may prove to be as important a development in birth-control technology as the contraceptive pill', said $\mathrm{Mr}$ David Griffin, a WHO official involved in the vaccine's development. 'The vaccine offers a number of advantages over many current methods, and this should make it a valuable addition to the options available to the public'. Advantages seem likely to include the simplicity of administering it, its long-term effectiveness, and the absence of drug-related side-effects.

The vaccine is based on a hormone, human chorionic gonadotrophin (hCG), which is produced soon after fertilization and is necessary for the establishment and maintenance of early pregnancy. When injected, the vaccine triggers an immune response that neutralizes the hormone, thus interrupting the reproductive process before the fertilized ovum has become implanted successfully in the womb.

The World Health Organization chose Flinders Medical Centre as the site of the trial because it has long been involved in the development of the vaccine, and because it offers the varied facilities needed for such complex trials.

WORLd Health Organization Avenue Appia 20 1211 Geneva 27 Switzerland.

\section{IUCN-CEP's European Committee for National Conservation Strategies}

Late in 1985, IUCN's Commission on Environmental Planning (IUCN-CEP) decided to form a 'European Committee for National Conservation Strategies' (EC-NCS), as a follow-up of the elaboration of the World Conservation Strategy and as a companion, on the European scene, of the Committee on the Ecodevelopment of Cultural Landscapes (CECL) which had been founded in 1971 mainly for the Central and East European countries.

The aim of EC-NCS is to encourage, share, and discuss, European supranational, national, and subnational, conservation strategies in order to learn from each other's experience. Common interests might also lead to the preparation of a European Conservation Strategy, and a strengthening of transfrontier conservation and antipollution activities. Examples of pertinent substantive topics for NCSs are trade and aid with the Third World, agricultural policy, post-industrial service economy and qualitative growth, and, of pertinent procedural topics, consensus building tactics and strengthening of links with international organizations.

At a meeting held in Brussels, Belgium, on 21-22 April 1986 in preparation for the Ottawa Conference on the
World Conservation Strategy, the EC-NCS realized that an immediate step should be due involvement in the Ottawa Conference on the World Conservation Strategy, and that another should be to have presentations on the European national and international conservation scenes. Later in the year, a more direct link should be established with the Council of Europe's 'European Campaign for the Countryside 1987-88', and with the 'European Environment Year 1987' which has been designated by the European Economic Community and should give further impetus to actions.

Potential members of the EC-NCS are invited by the undersigned to participate on an ad hoc basis amongst teams interested in and working on National and Regional Conservation Strategies in Western European Countries. Experts wishing to receive more information are requested to contact the undersigned.

\author{
MaX BöRLIN, Chairman of EC-NCS \\ Chemin des Bosquets \\ 1297 Founex \\ Vaud, Switzerland.
}

\section{Interuniversity Postgraduate Programme in Hydrology}

Under the sponsorship of the Belgian National Committee of the International Hydrological Programme and UNESCO, this programme, involving formal instruction extending over one or two years, includes an orientation in water pollution control. In addition, seminars-mainly presented by invited guest-lecturers-provide a broad background of both general and some specific environmental aspects.

\section{First Year}

This leads to a Diploma in Hydrology or a Certificate, and includes:

- Prerequisites (if necessary),

- Basic courses (420 hrs) in Open-channel hydraulics, Hydrometry, General meteorology and climatology, Hydrometeorology, Surface-water hydrology, 
Ground-water hydrology, Probability and statistics, Systems approach to water management Part I: Introduction, Water quality, treatment, and supply, Introduction to computer science and the use of hydrological databases, Introduction to computer programming, and Hydrological data analysis.

- Field training (30 hrs).

\section{Second Year}

This leads to a Master's degree in Hydrology for successful candidates, and includes:

- Optional courses (minimum $190 \mathrm{hrs}$ )

Orientation A: Surface-water hydrology:

Synoptic meteorology, Advanced hydraulics, Advanced surface-water hydrology, and Watershed management.

Orientation B: Ground-water Hydrology:

Flow through porous media, Advanced geohydrology, Hydrogeology and geophysical prospection, and Applied mathematical methods.

Orientation C: Water Pollution Control:

Water chemistry and water quality, Water-quality models, Hydraulics of wastewater collection and water supply, and Wastewater purification and water treatment.

Common to All Orientations:

Systems approach to water management Part II: Basic concepts, Statistical applications in hydrology, Teledetection techniques, Dam-sites and drilling techniques, and Time series analysis.

- Seminars (30 hrs)

- Field training (90 hrs)

- M.Sc. thesis

\section{Fellowships are Available in Five Frameworks}

1) Bilateral agreements with Belgium; applications must be introduced by national authorities at Belgian Embassies.
2) Multilateral programmes through United Nations Agencies; applicants must be introduced through the intermediate action of the UN regional representatives or the UN Department of Technical Cooperation for Development.

3) Exchange programmes as part of the International Cultural Agreements of several nations with Belgium; applications should be made through the appropriate authorities at a Belgian Embassy.

4) The European Development Fund for candidates from countries participating in the Convention of Lomé; applicants should contact the European Community (EC)-Delegation in their home country.

5) Programmes of international organizations (e.g. UNESCO-Participation Programme, WMO, WHO, FAO, etc.); applicants should contact the local representative in their home country.

The programme is located in Brussels at the Faculty of Applied Science, Free University of Brussels (VUB), and is also supported by the Universities of Antwerp, Ghent, and Louvain. Courses start on September 1st of each year, with English the medium of instruction. Students who have a Bachelor's degree (B.Sc. or B.Eng.) or its equivalent ( $\mathrm{Li}$ cence) will be considered for admission, female candidates being given special consideration as recommended by UNESCO. Students should have an excellent background in mathematics. Applications should normally be sent on the appropriate forms not later than February 1st of each year. Further information, including a brochure with application form, can be obtained from the undersigned:

A. VAN DER BEKEN, Professor Dr ir
Director of the Programme
Laboratory of Hydrology
Vrije Universiteit Brussel
Pleinlaan 2
B-1050 Brussels
Belgium.

\section{Major Corporations to Train Indonesian Officials in Industrial Environmental Management}

In a Pilot Fellowship programme to focus on environmental impact assessment, industrial audit procedures, and hazardous waste management, the Dow Chemical Company, Exxon, and Mobil Corporation, will train Indonesian government officials in industrial environmental management techniques. The new Fellowship programme is being established by the World Environment Center, a not-for-profit non-advocacy organization.

In its pilot phase, Indonesia Technical Assistance Project (ITAP) will provide the opportunities for three mid- and senior-level officials to spend up to three months with participating American companies. Each Fellow will receive individualized training, with emphasis on the abovementioned three important aspects of environmental concern.

The programme was established by the World Environment Center (WEC) at the request of Indonesia's Minister of Population and Environment, Dr Emil Salim. Direct costs covering US travel and living expenses will be contributed by participating companies, and international travel will be paid by Indonesia.

The Indonesian Technical Assistance Project is unusual in that, though governmentally-oriented, it is funded en- tirely by industry. Recent events having underscored the need for world-wide environmental management systems, this programme is a good example of how a partnership of government and industry can further such a goal.

Indonesia's Ambassador Soesilo Soedarman has commented that 'Indonesia welcomes this project as an example of cooperation with the United States' private sector in addressing an increasingly important issue: how to prevent effectively some of the potentially negative effects of industrialization.'

ITAP is an outgrowth of the Center's International Environment and Development Service (IEDS), which sends volunteers from 25 US companies to industrializing countries to perform environmental audits and provide training in industrial health and safety. The US $\$ 1.4$ million, fiveyears' programme (1983-88) is funded by the US Agency for International Development and US industry, and currently operates in the Near East and eastwards in Asia.

Among the companies that have participated in IEDS missions are Allied-Signal, Amax, Calgon, Combustion Engineering, Dow Chemical, Dundee Cement, Koppers, Pennzoil, Occidental Corporation, Tenneco, and US Steel. 